\title{
Limits to Trade Growth: Decomposing Manufacturing Trade
}

\author{
M. Ataman Aksoy ${ }^{1} \&$ Francis $\mathrm{Ng}^{1}$ \\ ${ }^{1}$ Former Staff Member of Development Research Group, World Bank, Washington, DC, USA \\ Correspondence: M Ataman Aksoy \& Francis Ng, Former Staff Member of Development Research Group, \\ World Bank, Washington, DC, USA. E-mails: ataman.aksoy@gmail.com, francis.ng2013@gmail.com
}

Received: December 2, 2016

Accepted: December 28, 2016

Online Published: January 10, 2017

doi:10.5539/ijef.v9n2p122

URL: http://dx.doi.org/10.5539/ijef.v9n2p122

\begin{abstract}
This paper decomposes manufacturing import growth rates in 5 large industrial and 8 large developing countries and measures the relative contributions of domestic demand and market share changes for 1986/87, 1991/92, 1996/97, 2001/02, 2006/07 and 2011/12. Imports as a share of domestic value added has increased significantly over this period and account between 70 to 80 percent of import growth during this period. Exports from developing countries and especially China account for the bulk of this increase. China is an exception to this development and its import shares have not increased and have actually decreased during the last period. Finally future trade growth rates are going to decrease. We show that most of the early growth of trade was caused by trade liberalizations from almost closed economies and initial import shares were very low so that small changes led to high trade growth rates. Now that the market shares are already very high, it is almost impossible to replicate similar growth rates.
\end{abstract}

Keywords: trade growth, global manufacturing trade, industrial and developing countries market shares, manufacturing value added, patterns of trade

\section{Introduction}

Aksoy and $\mathrm{Ng}$ (2013a, 2013b), decompose import growth rates for a set of large industrial and developing countries (five industrial and eight developing) and measure relative contributions of domestic demand and market share changes over the period 1991/92, 2001/02 and 2011/12 (using 2-year averages to minimize the annual fluctuations in trade and output). The five industrial countries were Canada, France, Germany, Japan, and the USA; the eight large developing countries were Brazil, Korea Rep., Malaysia, India, Mexico, South Africa, Turkey and China. The market share measure used was the share of manufacturing imports in gross manufacturing production expressed in current US dollars. Data used for domestic production was gross manufacturing output from UNIDO sources. Gross output was used for consistency with the trade data obtained from the UN COMTRADE Statistics database.

These two studies showed that: (a) all the economies in question had very significant import penetration caused by trade liberalizations that contributed to high trade growth rates; (b) there had been significant increases in the market shares of developing countries in these large industrial and developing countries, but close to 80 percent of the developing country market share gains were due to China alone.

Comments on these papers focused on a few areas. A first comment concerned the use of gross production data for domestic output. Some suggested that manufacturing value added would be a better indicator to estimate import shares. It was pointed out that imports as a share of GDP (value added) are more commonly used as the measure of import penetration than gross output. On the same issue others argued that UNIDO manufacturing value added data was quite different than other sources (WDI, IMF and other UN sources) and that the UNIDO gross output numbers could not easily be verified against other sources. Other common data sources do not report gross manufacturing output, so that using UNIDO gross production numbers could bias our analysis. Finally, many questioned whether the trends documented in the papers changed after the recession of 2008.

This paper tries to answer these questions and respond to these comments. We re-estimate market shares using manufacturing value added, defining market shares as imports of manufactured products divided by domestic manufacturing value added. For value added, World Bank WDI data are used as these are very close to other official and UN figures and are adjusted for exchange rate fluctuations. To place trade developments in a longer and more consistent framework, we added additional years and generated six observations for equal 5-year 
intervals. Our new periods of two year averages are 1986/87, 1991/92, 1996/97, 2001/02, 2006/07 and 2011/12. These years partially overlap with years used in the earlier work. These years also allow us to assess the performance of trade in the late 1980s and early 1990s, when the developing countries were liberalizing their trade regimes; the impact of the recession during 2001/02; the 2000s when world demand was growing very rapidly; and the post 2007 period when the world economy entered a serious recession. Because China has such a large impact on world manufacturing; we separate China from other developing countries.

Some of the results are similar to earlier findings, especially about the increasing integration of the world economy (Hoekman, 2015; Lim, 2014; World Bank, 2005, 2007) and the growth of south-south trade (Akyuz, 2012; Athukorala, 2011; IMF, 2011; OECD, 2006). But the details of trade growth, focus on manufacturing, and detailed trade shares are additional.

- Manufacturing imports as a ratio of domestic manufacturing value added in the 13 countries increased dramatically from 31.8 percent in 1986/87 to 71.5 percent in 2011/12. If China is excluded, the import share in the remaining sample increased from 31.8 percent to 85.1 percent at the end of the period. For industrial countries this ratio increased from 32.7 percent in 1986/87 to 83.8 percent in 2011/12. For developing countries, the growth is even more dramatic, with import shares increasing from 25.7 percent to 89.1 percent in 2011/12. These increases are primarily driven by trade liberalizations.

- Most of the rapid trade growth observed over this period reflects market share increases and not so much growth of output. Between 70 to 80 percent of import growth is caused by market share changes.

- For the industrial countries, 70 percent of market share increases are due to developing countries, of which half is due to China alone. After 2001, the developing countries' contribution increases to 85 percent, with China accounting for 65 percent of the increase.

- For the developing countries, market share increases are driven by China and other developing countries. For the period as a whole developing countries account for over 60 percent of market share changes, with China accounting for 50 percent of this change. After 2001, China's contribution increases to 80 percent, and that of industrial countries decreases. China's is far more important for the developing countries.

- China is an exception to other large developing and industrial countries in that its import shares have not increased at the same rates as the others. In the post 2008 period, China has become more autarchic - its share of imports from other countries has actually decreased as a share of its manufacturing value added.

- Import shares have increased from about 20-30 percent to around 90 percent, maintaining similar growth rates would require larger and larger absolute market share increases. Since this is not likely, trade growth rates will be declining independent of any structural change.

\section{Data}

For this study manufacturing value added data is from WDI of World Bank in current US dollars adjusted for real exchange rate changes against the US dollar (Note 1). These series are consistent with trade data from the UN COMTRADE database which is also denominated in current US dollars. The definition of industrial countries is based on the traditional IMF definition that includes the EU15, United States, Canada, Japan, Australia, New Zealand, Iceland, Norway, and Switzerland. Developing countries include all countries in the world except the 23 industrial ones. Free Trade Agreement (FTA) developing countries are Mexico for US and Canada, and Eastern European countries and Turkey for France and Germany. The 1986/87, 1991/92, 1996/97, 2001/02, 2006/07 and 2011/12 periods are used as benchmarks to estimate growth rates and import shares. Two year averages are used to minimize the annual fluctuations in output and trade. Although the periods are of same length, we have presented the trade growth rates as annual rates.

Import growth in these countries is decomposed into changes due to demand increases and changes due to market share changes. Demand growth is the annual rate of growth of domestic manufacturing value added in current US dollars adjusted for real exchange rate changes. The contribution of demand changes is estimated assuming a constant share of imports in value added between the two time periods, i.e. the market shares do not change. Market share changes are then estimated as the difference between the actual import growth rate and the import growth rate under a constant market share assumption.

\section{Analysis}

\subsection{The Global Picture}

In Figure 1, we present the import growth rates for the sample countries separated into demand (output) and market share changes. Given the large impact of China, especially in the later periods, we separate the sample 
into with and without China.

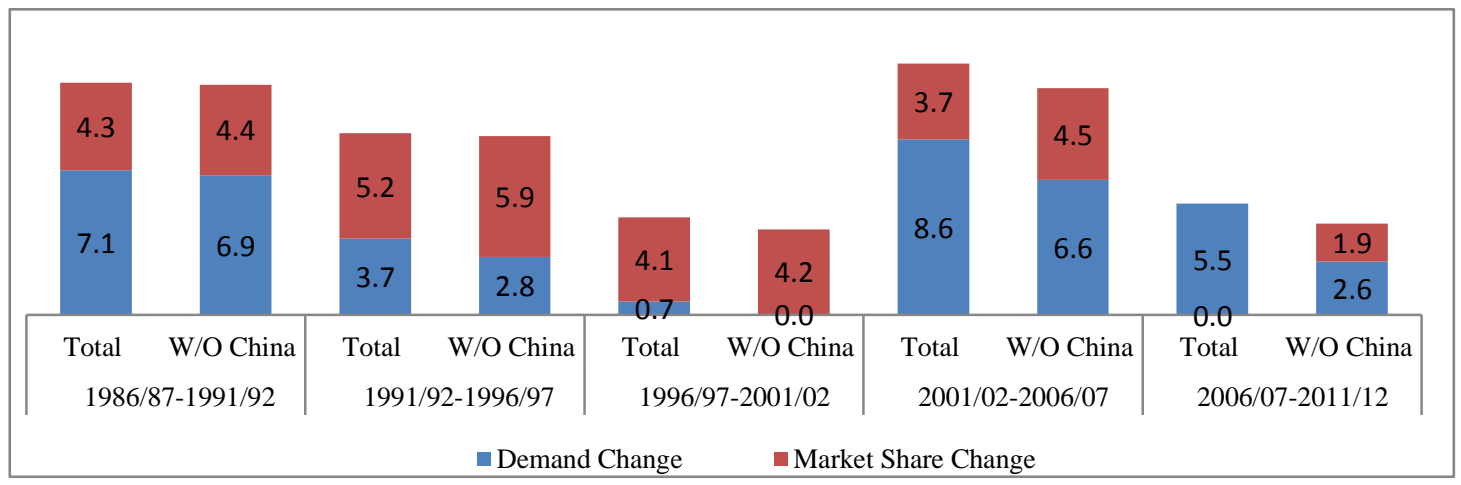

Figure 1. Global manufacturing import growth, with and without China (percent p.a.)

An important determinant of the growth of trade is the growth of output. The second component is the market share increases. When imports take a larger share of domestic market, trade expands at faster rates. This is driven by significant trade liberalizations that have taken place and this is the component that trade analysts focus on. For this reason we present both the output and market share increases separately to show the effects of both on import growth rates.

Total import growth for these countries was high during 1986/87-1991/92 and 1991/92-1996/97 periods; 11.4 and 8.9 per annum (p.a.) for countries with China and 11.3 and 8.7 percent p.a. for the countries without China. During 1996/97- 2001/02, import growth slows down to 4.8 and 4.2 percent p.a. respectively. Since there is almost no value added growth during this period, import growth is solely driven by market share increases. There is a rebound in growth rates during 2001/02- 2006/07 period to 12.3 and 11.9 percent p.a. respectively. This is partially due to an output rebound from the recession of the earlier period. Finally, after the recession of 2008, 2006/07-2011/12, trade growth slows dramatically to 5.4 percent p.a. for countries with China and 4.5 percent p.a. for countries without China. Even in this recession, trade growth rates are higher than they were during the recession of 1996/97-2001/02. What is different is the contribution of market share changes which are much smaller during the last recession.

Figure 1 also shows the impact of China on global manufacturing trade. Its impact increases over time and it is different than the rest of the sample. It has higher output growth and lower market share increases than other countries in the sample.

Figure 2 shows the share of imports in adjusted value added over this period. It clearly demonstrates the very large increases in market shares globally. This is driven by significant trade liberalizations in almost all countries along with the increasing competitiveness of most countries, especially the developing ones (Aksoy \& $\mathrm{Ng}, 2014$; Akyuz, 2011; Hanson \& Robertson, 2008). Development of product chains driven by large multinational companies have also contributed (Cheptea, 2005; Hoekman, 2015). Import shares have increased from about 32 percent at the beginning of the period to 85 percent for the sample without China and 72 percent with China by the end of the period. This corresponds to an almost threefold increase in 25 years.

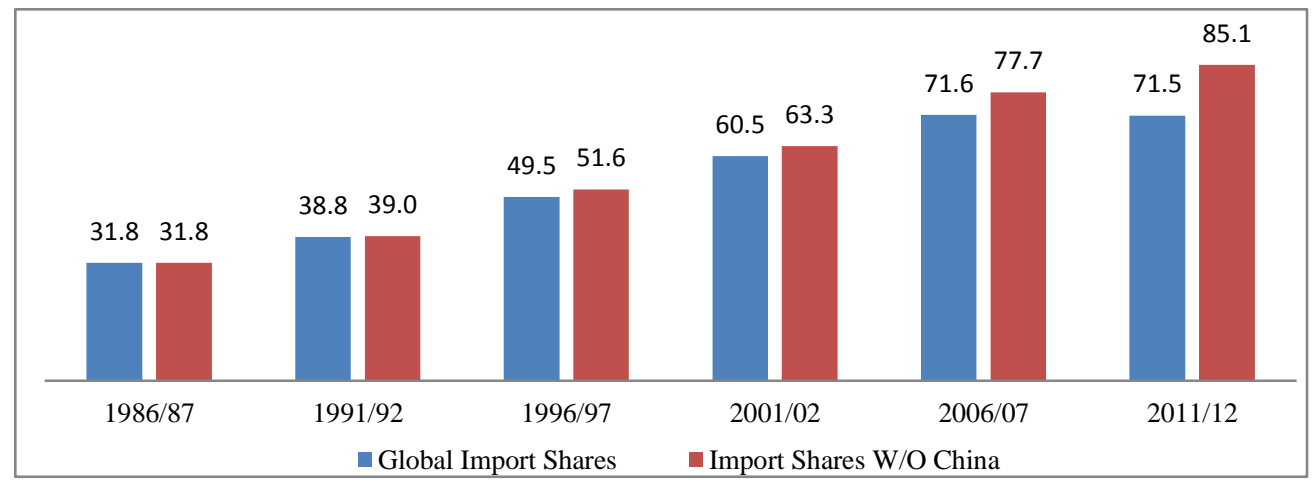

Figure 2. Global manufacturing import shares (average in percent) 


\subsection{Disaggregated Analysis}

Industrial and developing countries' trade growth might have evolved differently. Therefore in the next section we analyze two groups of countries separately. The data suggests that trade growth cycles are very similar in both groups of countries while the actual growth rates differ. We exclude China from these two subgroups and treat it separately as a third group.

Figures 3 and 4 show the annualized growth rate of shares of imports for 5 industrial and 7 developing countries. There are 3 periods of high import (trade) growth and 2 periods of relatively low growth.

Industrial Countries: Output (value added) growth has slowly decelerated from late 1980s to 2001, where it turns negative for 1997-2002 period. There is an improvement to more than 5 percent p.a. during the 2001/02 -2006/07. During the last recession period of 2006/07-2011/02, output growth rates decelerate to 1.5 percent p.a.

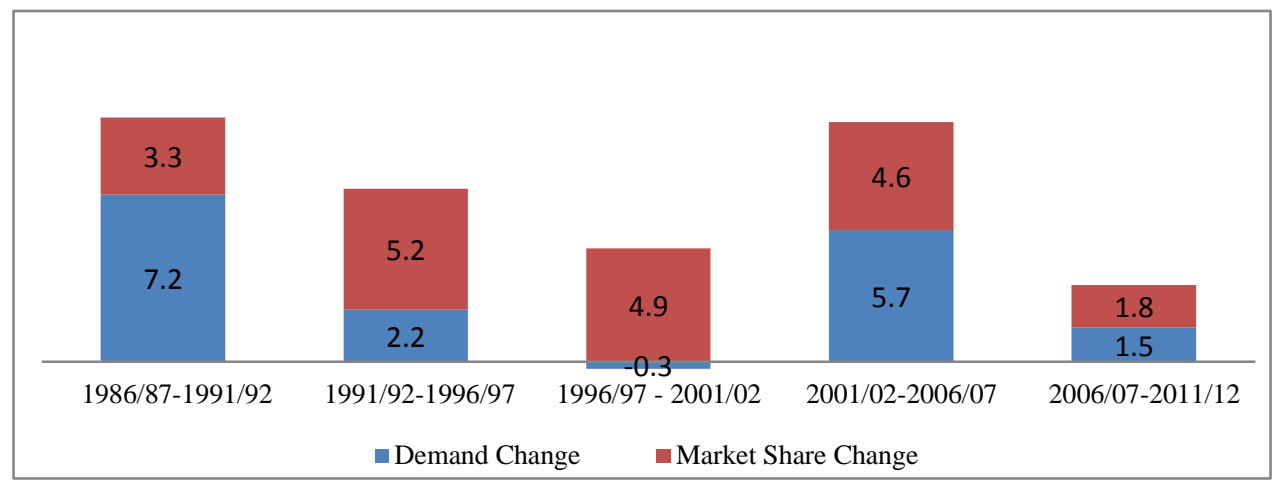

Figure 3. Import growth in 5 industrial countries (percent p.a.)

Growth rates of manufacturing sector value added during 2008 crisis are not much lower than the growth rates than during the early 1990s and much higher than late 1990s (1996/07-2001/02). This is because during the late 1990s, France, Germany, and Japan all had negative growth rates. During the post 2008 period, only France has negative value added growth, while the other four countries have positive but low growth.

What differentiates the last period is the very slow growth of market share increases. Part of this can be explained by the lower import shares in the early periods. As the shares increase, we do expect a decline in growth rates. This is a point we will return in the last section.

Developing Countries: Annual output growth rates are much higher in the 7 developing countries but the pattern of growth in the 5 industrial countries and 7 developing countries are very similar. Output growth rates decelerate during the first three periods with an uptick during the early 2000s. It is interesting that output growth rates are higher during the last recession (2006/07-2011/12) than output growth rates during mid 1990s (1996/97-2001/02). Earlier period has a more significant recession, affecting both the industrial and developing countries. Even with the serious last recession, and with reasonably high imports shares, the import share increases are still 1.7 percent p.a.

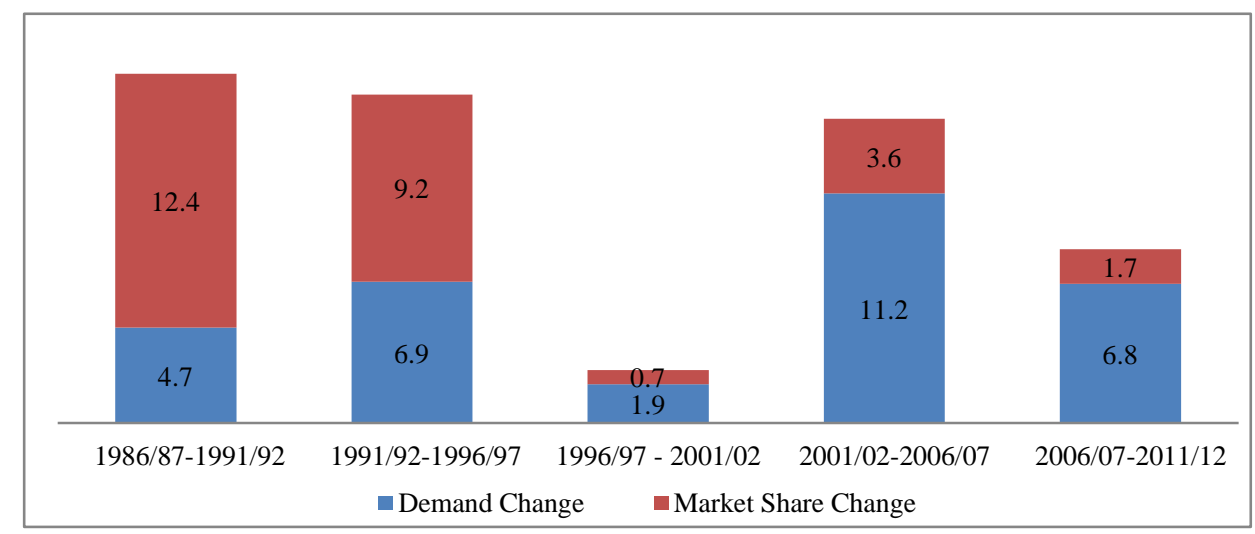

Figure 4. Import growth in 7 developing countries (percent p.a.) 
It is obvious that trade liberalizations undertaken during the late 1980s and early 1990s were the main determinants of import share increases. That is why we see huge increases in market share changes during the first two periods. A related question is the acceleration of growth during the 2001-2006 period. While there are many causes for this acceleration, part of the reason might be a rebound from lower growth a period earlier.

\subsection{Market Shares}

Major driving force for the trade growth has been the increases in market shares and not so much output increases. This is especially true for the 5 industrial countries where the contributions of market share changes are much greater than the increases in value added. Annual growth rate of total imports of the 5 industrial countries for the whole period are 7.2 percent p.a., while the growth rate of output was only 3.2 percent p.a. For the 7 developing countries, the same rates are 11.7 versus 7.3 percent p.a. If the trade growth had grown at the same rate as output, that means there had been no market share change, the resulting import values would be only 20 percent of what actually in 2011/12, and for the developing countries imports would be 30 percent of the actual value. In other words, between 70 to 80 percent of import growth are caused by market share changes. So the biggest driver of trade growth over the last few decades has been caused by import liberalizations and increases in competitiveness.

For developing countries, import share increases are far larger during late 1980s and early 1990s when most of these countries were undertaking trade reforms. It is clear that the reforms have not continued at the same rate or by that time most of the trade regime had been liberalized. Another development is the pattern of integration of some of the developing countries into the world economy. Countries such as Malaysia, Mexico, and to a lesser extent China and Korea, have started as export platforms where they import most of the parts/components and assemble them for export. So initially their import to value added ratios shoot up. Over time many of the parts/components start being produced domestically so the import penetration ratios decline or at least import share growth slows down (Akyuz, 2013; UNCTAD, 2012; World Bank, 2010, 2011). This explains part of the slowdown in the increase in import shares for the developing countries.

To illustrate how the market shares have changed and which groups of countries are responsible for the changes, we have separated the exporters into 5 groups for industrial countries and 4 groups for developing countries. For industrial countries we have China as a separate group along with Free Trade Agreements (FTA) countries, and all other countries. FTA countries are EU for France and Germany and NAFTA for US and Canada. We break these further into FTA among industrial countries, which are the imports from original EU 15 countries for France and Germany and imports from each other for US and Canada. FTA imports from developing countries are imports from Mexico for US and Canada and other EU 12 members and Turkey for France and Germany. All other imports are also separated into imports from other developing and industrial countries.

Table 1. Global manufacturing import shares (percent of domestic adjusted value added)

\begin{tabular}{lcccccc}
\hline & \multicolumn{5}{c}{ Share of imports in manufacturing value added (\%) } \\
\cline { 2 - 6 } Country Group & $1986 / 87$ & $1991 / 92$ & $1996 / 97$ & $2001 / 02$ & $2006 / 07$ & $2011 / 12$ \\
\hline Industrial Countries (5): & 32.7 & 38.2 & 48.8 & 62.0 & 76.6 & 83.8 \\
Global Imports & 0.5 & 1.6 & 3.6 & 6.8 & 14.0 & 18.7 \\
From China & 14.1 & 17.1 & 20.5 & 25.5 & 29.9 & 31.0 \\
From FTAs & 13.3 & 15.8 & 17.3 & 19.8 & 23.0 & 22.3 \\
$\quad$ Industrial countries & 0.8 & 1.2 & 3.2 & 5.7 & 6.9 & 8.7 \\
$\quad 18.2$ & 19.5 & 24.7 & 29.7 & 32.6 & 34.1 \\
$\quad$ Developing countries & 13.4 & 13.5 & 16.1 & 18.8 & 19.9 & 19.9 \\
All other countries & 4.8 & 6.0 & 8.6 & 10.8 & 12.7 & 14.2 \\
$\quad$ Industrial Countries & & & & & & \\
$\quad$ Developing Countries & 25.7 & 44.9 & 67.7 & 70.1 & 82.4 & 89.1 \\
Developing Countries (7): & 0.1 & 0.8 & 2.3 & 4.5 & 13.6 & 19.7 \\
Global Imports & 4.0 & 9.0 & 16.7 & 20.6 & 16.4 & 14.2 \\
From China & 21.5 & 35.1 & 48.7 & 45.1 & 52.3 & 55.1 \\
From FTAs - Industrial Co. & 18.6 & 28.4 & 37.3 & 31.8 & 33.6 & 32.6 \\
All other countries & 2.9 & 6.7 & 11.4 & 13.3 & 18.7 & 22.5 \\
$\quad$ Industrial Countries & & & & & & \\
$\quad$ Developing Countries & & &
\end{tabular}

Sources: Computations are based on WDI and COMTRADE databases.

One of the reasons for this classification is to account certain discrete events that make a large difference in changing market shares. One important event is the inclusion of some developing countries into regional trade 
arrangements. In our sample of countries, imports from Mexico for US and Canada, caused primarily by NAFTA, make a big difference in their import growth rates after 1994. Similarly, expansion of EU to Eastern Europe and Turkey during the 1990s also leads to a spurt in imports from these countries which are classified as developing countries. We observe these one-off gains in the import shares of Germany and France. Import shares by FTA countries (Mexico for US and Canada, and Eastern Europe and Turkey for France and Germany) almost double between 1996/97 and 2001/02 (Table 1). Second important development is China joining the WTO which increases the imports from China at much faster rates. Since China joined the WTO in 2001, its shares in these markets have more than doubled.

Table 1 shows the global manufacturing import shares in 5 industrial and 7 developing countries. This table highlights few points. First, all groups of countries have increased their shares in these markets suggesting greater integration of these economies. Second, developing countries which were much more closed at the beginning of the period are now much more open. Third, despite the serious recession, import shares continue to increase. And finally, the slowdown in import shares is more prominent among imports from industrial countries than from developing ones. For the developing countries, share of imports from industrial countries have actually decreased and they have either decreased or not increased for industrial countries. All groups of developing countries have continued to increase their market shares despite the recession.

Another way of looking at this phenomenon is to estimate the contribution of each subgroup to market share changes (Table 2). This can be done by estimating the percentage contribution of each group of countries to market share increases.

Table 2. Contribution of market shares in manufacturing imports

\begin{tabular}{|c|c|c|c|c|c|}
\hline \multirow[b]{2}{*}{ Country Group } & \multicolumn{5}{|c|}{ Contribution of each group (\%) } \\
\hline & 1986/87-1991/92 & 1991/92-1996/97 & 1996/97-2001/02 & 2001/02-2006/07 & 2006/07-2011/12 \\
\hline \multicolumn{6}{|l|}{ Industrial Countries (5): } \\
\hline Global Imports & 100.0 & 100.0 & 100.0 & 100.0 & 100.0 \\
\hline From China & 19.9 & 19.5 & 24.4 & 49.1 & 64.8 \\
\hline From FTAs & 55.5 & 32.0 & 37.9 & 30.6 & 15.0 \\
\hline Industrial countries & 46.4 & 13.6 & 19.1 & 22.1 & -10.0 \\
\hline Developing countries & 9.0 & 18.4 & 18.8 & 8.5 & 25.0 \\
\hline All other countries & 24.7 & 48.5 & 37.7 & 20.3 & 20.3 \\
\hline Industrial Countries & 1.2 & 24.8 & 20.5 & 7.5 & -0.2 \\
\hline Developing Countries & 23.5 & 23.7 & 17.3 & 12.8 & 20.5 \\
\hline \multicolumn{6}{|l|}{ Developing Countries (7): } \\
\hline Global Imports & 100.0 & 100.0 & 100.0 & 100.0 & 100.0 \\
\hline From China & 3.5 & 6.6 & 90.6 & 74.8 & 90.9 \\
\hline From FTAs - Industrial Co. & 26.0 & 33.8 & 160.8 & -33.7 & -33.3 \\
\hline All other countries & 70.5 & 59.6 & -151.4 & 58.8 & 42.3 \\
\hline Industrial Countries & 51.2 & 38.8 & -231.7 & 14.7 & -13.9 \\
\hline Developing Countries & 19.3 & 20.8 & 80.3 & 44.1 & 56.3 \\
\hline
\end{tabular}

Sources: Computations are based on WDI and COMTRADE databases.

Industrial countries: Table 2 shows the trends more clearly. Market share changes increase in post 1990 period. As expected, the contribution of China increases from about 20 percent, to 65 percent in 2011/12. Similarly developing countries within FTA arrangements increase their shares with the NAFTA and EU accession of Eastern Europe and Turkey. Industrial countries contribute less and actually lose market shares. One possible reason for this might be that the trade regimes among industrial countries were already quite liberal but the developing countries started their integration into the world economy during the late 1980s and 90s.

The increase in import shares really start after 1991 and continue increasing until the recession of 2008 . Increases are driven initially by the FTA arrangements followed by the increase by China. For the period as a whole, 70 percent of the market share increases are contributed by developing countries and China accounts for half of this. Looking at the last decade, i.e. post 2001; developing countries account for 76 percent of the market share change but now China accounts for 72 percent of the developing country market share gains and 55 percent of all market share changes.

Developing Countries: Market share of imports are almost triple during this period. These 7 countries are now more open than the industrial countries. But the biggest gains are in the late 1980s and 1990s when most of the major developing countries were undertaking trade reforms. There are also surges caused by trade arrangements. 
Imports from industrial FTA countries (by Turkey and Mexico) surge with NAFTA and EU accession. But this is just a substitution of imports from other industrial countries to EU and NAFTA countries. Of course the surges then slowly dissipate. But as a trend, the initial gains are made mostly by industrial countries and starting around 2001, developing countries make most of the gains, and even take market shares from industrial countries.

For the period as a whole, China contributes about 31 percent of the gains, FTA countries 16 percent and all other countries contribute 53 percent. Other developing countries contribute only 31 percent and the rest is contributed by other industrial countries. China dominates the market share changes and explains close to 90 percent of the market share gains after 2001 (Aksoy \& Ng, 2014).

\subsection{China}

Given the tremendous impact of China, we decided to look at it separately and not as a part of the large developing countries. Figure 5 shows the pattern and composition of import growth for China.

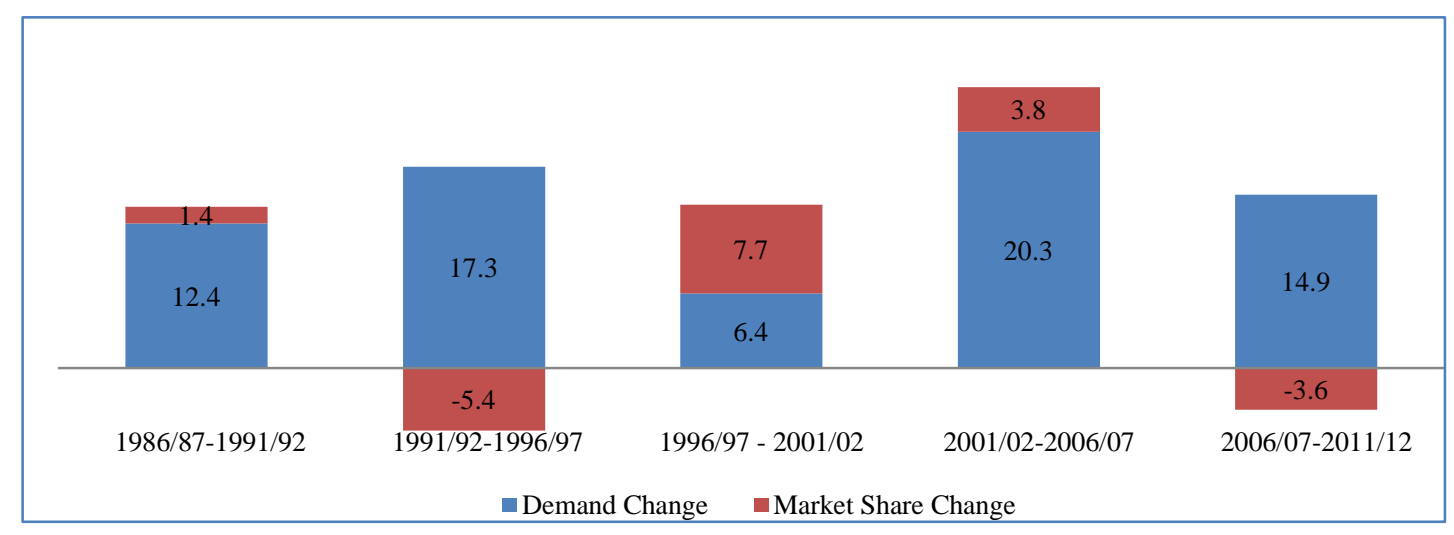

Figure 5. China's import growth (percent p.a.)

First, unlike most of the other countries, the contribution of market share changes is not the main driver of import growth in China. The main driver of import growth is the very fast rate of growth of value added. For comparison, the average growth rate of value added is around 6 percent p.a. for the 7 developing countries but it is 14 percent p.a. for China. The other countries with sizable manufacturing sectors and have high value added growth are Korea and India which only grew at 10 percent p.a.

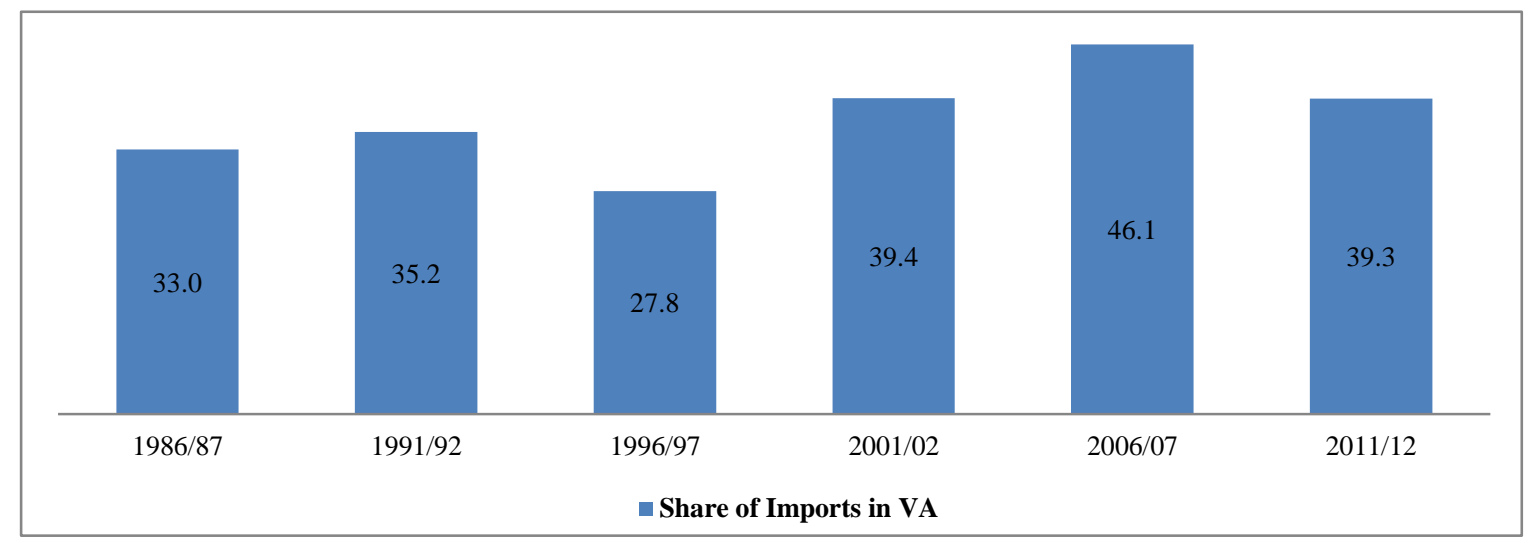

Figure 6. China's share of imports in manufacturing value added

As of 2011/12, among the 13 countries in our sample, China has the second lowest share of imports at 39 percent (Figure 6). The only other country that has a lower import share is Japan at 36 percent. Furthermore, most other countries had continuously increasing import shares, while China had two periods where import shares declined and from a relatively low base. Even Japan which started with very low import shares shows continuously increasing import shares. To illustrate the differences, Figure 7 shows the import shares of 4 major countries with large and advanced manufacturing sectors. 


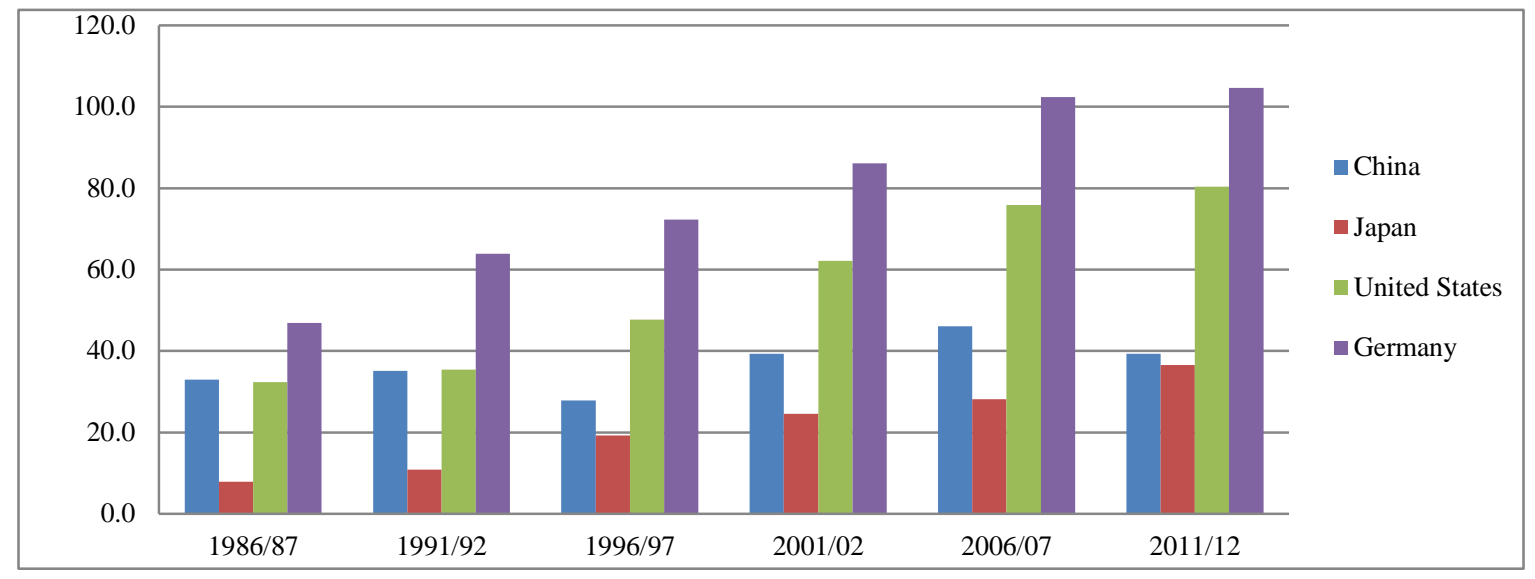

Figure 7. Share of imports in manufacturing value added

Other countries with major manufacturing sectors all show significant increases in integration with the rest of the world. Their import shares have increased two to threefold over this period while there is little increase in China's import share. Rapid increase in import shares after 1996 is reversed after 2006 and by the end period import shares are both low and similar to where they were in 1986.

\section{Trade Growth Deceleration}

One of the important debates about trade growth has been its deceleration, especially after the 2008 recession (ADB, 2014, 2016; Constantinescu, Mattoo, \& Ruta, 2014, 2015; Hoekman, 2015; World Bank, 2012, 2013). Our data also indicates a serious slowdown driven both by slow output growth and very little change in import shares. While we have another period of low growth during 1996/97-2001/02 period, that was caused primarily by low output growth. During the post 2008 period the low trade growth is mostly caused by low rate of growth of market shares. The problem is a statistical one. As the market shares increase, a similar change in absolute market share change corresponds to a lower growth rate. Since market shares cannot increase forever, the growth rates start to decline, even if the absolute increases are similar.

Figure 8 shows the relationship between the level and change in market shares. The data consists of 65 observations one for each country and period. We tested for the following relationships. First we tested whether there are any correlations between value-added growth rates and market share changes. There is no correlation between them. So there is no spillover from output to imports. Then we tested whether the market share changes had declined in the last period as argued. There is no statistical difference between the last period and the other periods. Actually none of the periods have a statistically different market share change rate than other periods. And finally we tested the relationship between the level of market shares and their change. The levels of market shares are negatively correlated with market share change rates. As market shares increase, their growth rates decline. We show this relation in Figure 8 below.

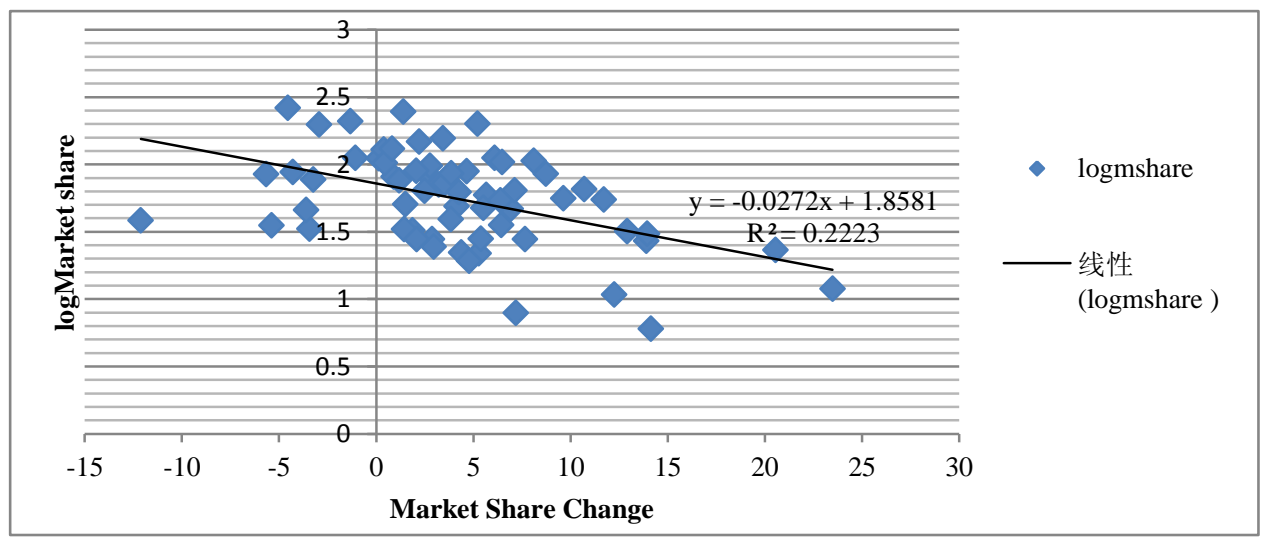

Figure 8. Market share: levels and changes 
In the regression, we also observed that China was an outlier in this regression. We added a China dummy to the equation which was significantly negative ( $\mathrm{t}$-values in parentheses).

Market share change rate $=19.99-3.85 \log ($ marketshare $)-5.44$ China

$\mathrm{R} 2=0.28 ; \mathrm{n}=65$

** China dummy is significant at 97 percent; the other two are significant at 99 percent.

Since the market share growth rates are by definition negatively correlated with market shares and thus decrease over time, we looked at the absolute increases in market shares. Table 3 shows the absolute contribution of each subgroup to the overall change in market shares. For example, for industrial countries between 1986/87 and 1991/92, share of imports as a percentage of domestic value added increased from 32.7 percent to 38.2 percent (Table 1). So the total increase is 5.4 percentage points. This is the total change over the five years between the market shares in two periods. This percentage change increases to 7.2 percentage points in the last period. The 5.4 percentage point increase in import shares in the first period corresponds to an annual growth of 3.3 percent p.a. while 7.2 percentage point increase during the last period only corresponds to a 1.8 percent increase p.a.

Table 3. Composition of market share changes in global manufacturing imports

\begin{tabular}{|c|c|c|c|c|c|}
\hline \multirow[b]{2}{*}{ Country Group } & \multicolumn{5}{|c|}{ Absolute contribution over 5 years $(\%)$} \\
\hline & 1986/87-1991/92 & 1991/92-1996/97 & 1996/97-2001/02 & 2001/02-2006/07 & $2006 / 07-2011 / 12$ \\
\hline \multicolumn{6}{|l|}{ Industrial Countries (5): } \\
\hline Global Imports & 5.4 & 10.7 & 13.1 & 14.6 & 7.2 \\
\hline From China & 1.1 & 2.1 & 3.2 & 7.2 & 4.7 \\
\hline From FTAs & 3.0 & 3.4 & 5.0 & 4.5 & 1.1 \\
\hline Industrial countries & 2.5 & 1.4 & 2.5 & 3.2 & -0.7 \\
\hline Developing countries & 0.5 & 2.0 & 2.5 & 1.2 & 1.8 \\
\hline All other countries & 1.3 & 5.2 & 5.0 & 3.0 & 1.5 \\
\hline Industrial Countries & 0.1 & 2.6 & 2.7 & 1.1 & 0.0 \\
\hline Developing Countries & 1.3 & 2.5 & 2.3 & 1.9 & 1.5 \\
\hline \multicolumn{6}{|l|}{ Developing Countries (7): } \\
\hline Global Imports & 19.2 & 22.8 & 2.4 & 12.3 & 6.7 \\
\hline From China & 0.7 & 1.5 & 2.2 & 9.2 & 6.1 \\
\hline From FTAs - Industrial Co. & 5.0 & 7.7 & 3.8 & -4.1 & -2.2 \\
\hline All other countries & 13.6 & 13.6 & -3.6 & 7.2 & 2.8 \\
\hline Industrial Countries & 9.8 & 8.8 & -5.5 & 1.8 & -0.9 \\
\hline Developing Countries & 3.7 & 4.7 & 1.9 & 5.4 & 3.8 \\
\hline
\end{tabular}

Sources: Computations are based on WDI and COMTRADE databases.

These results corroborate our earlier findings. Decline in market share growth rates is primarily coming from imports of industrial countries. In terms of imports from developing countries, the decline is minimal.

Table 3 also shows that during 1996/97-2001/02 recession, industrial countries continued to have increases in import shares - mostly driven FTAs - while developing countries reacted by reducing import growth, that is almost no change in import shares.

\section{Conclusion}

In this paper we focus on trends in world manufacturing trade over the last 25 years by analysing the import patterns of 13 large industrial and developing countries that account for more than 50 percent of world manufacturing output and trade. Imports as a ratio of domestic value added has increased significantly over this period and accounts for 70 to 80 percent of import growth during this period. Exports from developing countries and especially China account for the bulk of this increase. China is an exception to this development in that its import shares have not increased - and actually decreased during the most recent period.

Given that bulk of the rapid trade growth reflects market share changes, future trade growth rates are going to decrease significantly. Most of the early growth of trade was caused by trade liberalizations from almost closed economies. Initial market shares were very low so that any change led to high growth rates. Now that market shares are very high, it is almost impossible to have the same growth rates in the same path even if import shares 
continue to increase at the same absolute levels.

These results also indicate that the export or trade led growth which has been the dominant policy strategy over the last few decades needs to be rethought. First, there needs to be another round of trade reforms eliminating restrictions in some subsectors where tariff peaks and other impediments still exist. Second, trade has to expand in areas other than manufacturing. And third, policies to readjust internal and external demand needs to be analyzed without endangering the gains achieved with global integration.

\section{Acknowledgments}

The authors are grateful to Yilmaz Akyuz, John Baffes and Tanju Yurukoglu for useful comments and suggestions on the initial draft of this study.

\section{References}

Aksoy, M. A., \& Francis, N. (2013a). Demand Growth versus Market Share Gains: Decomposing World Manufacturing Import Growth, World Bank Policy Research Working Paper, No. 6375, Washington DC: World Bank, February. Retrieved from https://doi.org/10.1596/1813-9450-6375

Aksoy, M. A., \& Francis, N. (2013b). Demand Growth versus Market Share Gains: Decomposing World Manufacturing Import Growth. Modern Economy, 4(6), 431-447, June. Retrieved from http://www.scirp.org/journal/PaperInformation.aspx?PaperID=33130

Aksoy, M. A., \& Francis, N. (2014). Increased Export Performance and Competitiveness of Developing Countries is Mainly a China Story. Voxeu.org and CEPR, May 3. (Also see RSCAS Policy Papers, PP2014/07, European University Institute, July). Retrieved from http://voxeu.org/article/south-south-trade-it-s-mostly-china

Akyüz, Y. (2011). The Global Economic Crisis and Trade and Growth Prospects in East Asia. ADB Economic Working Paper Series, No. 242, Manila: Asian Development Bank, January. Retrieved from https://www.adb.org/publications/global-economic-crisis-and-trade-and-growth-prospects-east-asia

Akyüz, Y. (2012). The Staggering Rise of the South? Research Papers, No. 44, Geneva: South Centre, March. Retrieved from https://www.southcentre.int/research-paper-44-march-2012/

Akyüz, Y. (2013). Waving or Drowning: Developing Countries after the Crisis. Research Papers, No. 48, Geneva: South Centre, June. Retrieved from https://www.southcentre.int/research-paper-48-june-2013/

Asian Development Bank. (2012, 2014, 2016). Asian Development Outlook. Manila: ADB. Retrieved from https://www.adb.org/publications/series/asian-development-outlook

Athukorala, P. (2011). South-South Trade: An Asian Perspective. ADB Economic Working Paper Series, No. 265, Manila: Asian Development Bank, July. Retrieved from https://www.adb.org/publications/south-south-trade-asian-perspective

Cheptea, A., Gaulier, G., \& Zignago, S. (2005). World Trade Competitiveness: A Disaggregated View by Shift-Share Analysis. CEPII Working Paper, No. 2005-23, Paris: CEPII, December. Retrieved from http://www.cepii.fr/PDF_PUB/wp/2005/wp2005-23.pdf

Constantinescu, C., Mattoo, A., \& Ruta, M. (2014). Slow Trade. Finance \& Development, 51(4), 1-4. Retrieved from http://www.imf.org/external/pubs/ft/fandd/2014/12/pdf/constant.pdf

Constantinescu, C., Mattoo, A., \& Ruta, M. (2015). The Global Trade Slowdown: Cyclical or Structural? World Bank Policy Research Paper, No. 7158, Washington DC: World Bank, January. (Also see IMF Working Paper, WP/15/6, 2015). Retrieved from http://www.imf.org/external/pubs/cat/longres.aspx?sk=42609.0

Hanson, H. G., \& Raymond, R. (2008). China and the Manufacturing Exports of Other Developing Countries. NBER Working Paper, No. 14497, November. Retrieved from http://www.nber.org/papers/w14497

Hoekman, B. (2015). The Global Trade Slowdown: A New Normal? EUI \& CEPR Press. Retrieved from http://voxeu.org/content/global-trade-slowdown-new-normal

IMF. (2011). New Growth Drivers for Low-Income Countries: The Role of BRICs. IMF Strategy, Policy and Review Department, Washington DC: IMF. Retrieved from https://www.imf.org/external/np/pp/eng/2011/011211.pdf

Mah-Hui, L. (2014). Globalization, Export-Led Growth and Inequality: The East Asian Story. Research Papers, No. 57, Geneva: South Centre, November. Retrieved from https://www.southcentre.int/research-paper-57-november-2014/ 
OECD. (2006). South-South Trade: Vital for Development. Policy Brief, OECD Observer, August. Retrieved from http://www.oecd.org/development/37400725.pdf

UNCTAD. (2012). Trade and Development Report. Geneva: UNCTAD. Retrieved from http://unctad.org/en/PublicationsLibrary/tdr2012_en.pdf

World Bank. (various issues). Global Economic Prospects. World Bank publication, Washington DC: World Bank. Retrieved from https://www.worldbank.org/en/publication/global-economic-prospects

\section{Note}

Note 1. Value added data is converted from local currency into US dollars at the existing rate of exchange. Swings in exchange rates lead to large changes in the US dollar value of local production independent of real changes. To minimize this effect, we adjust the valuation of local value added for real exchange rate changes.

\section{Copyrights}

Copyright for this article is retained by the author(s), with first publication rights granted to the journal.

This is an open-access article distributed under the terms and conditions of the Creative Commons Attribution license (http://creativecommons.org/licenses/by/4.0/). 